\title{
RECENT CHANGES IN THE JAPANESE WHOLESALE SYSTEM AND THE IMPORTANCE OF THE SOGO SHOSHA
}

\author{
Roy Larke \\ College of Business, Rikkyo University, Tokyo \\ and \\ Keri Davies \\ Institute for Retail Studies, University of Stirling
}

August 2006

Roy Larke

College of Business

Rikkyo University

Tokyo

Keri Davies*

Institute for Retail Studies

University of Stirling

Stirling FK9 4LA

Scotland, United Kingdom

Tel: (44) 1786467408

Fax: (44) 1786465290

e-mail: b.k.davies@stir.ac.uk

* Contact Author 


\section{RECENT CHANGES IN THE JAPANESE WHOLESALE SYSTEM AND THE IMPORTANCE OF THE SOGO SHOSHA}

\section{A B S T R A C T}

Interest in Japanese distribution as a field of academic study has waned in recent years, but there is a continuing concern with the activities of Japan's general trading companies or Sogo Shosha. This research has concentrated largely on their function as international trade intermediaries but it has overlooked their role in the domestic economy. In recent years, the same Sogo Shosha have expanded their involvement in domestic distribution, in particular into food wholesaling, but more recently into retailing. The aim of this paper is to explore the extent of this involvement and to present an analysis of the reasons behind such a shift from both a managerial and a theoretical perspective. Further, we go on to look at the current and future consequences of such large, internationally powerful companies taking a significant share in domestic distribution in Japan.

Keywords:

Japan, trading companies, sogo shosha, wholesaling, distribution structure, channel strategy 


\section{Introduction}

The Sogo Shosha or Japanese General Trading Companies have made significant investments in the wholesaling sector in Japan in recent years, taking them away from their traditional business model of facilitating international trade. This paper discusses the scale and scope of these investments and places them into the context of the wider changes in the Japanese distribution sector and in terms of the roles being played by Sogo Shosha in the Japanese economy.

\section{Sogo Shosha in context}

The Sogo Shosha are an integral part of Japan’s economy both historically and in the present day. Their historical importance is well recognised and they have been the subject of a large volume of literature (Yoshino, 1976; Young, 1979; Yoshihara, 1982; Kojima \& Ozawa, 1984; Yoshino \& Lifson, 1986; Eli, 1990; Kensy, 2001). Furthermore, much of the literature relating to General Trading Companies (GTC) around the world makes specific reference to Sogo Shosha, noting that many countries actually set out to emulate the Japanese model (Young, 1979). That said, most authors have labelled the Japanese model as ‘unique’ (Yoshihara, 1987; Yonekawa, 1990). While international trade is a core activity, the Sogo Shosha play a role within the domestic Japanese economy that has brought them far beyond the models of international trade intermediary (ITI)(Ellis, 2001; 2003). For this reason, this paper uses the terms Sogo Shosha or Shosha rather than GTC or other translation to signify the Japanese companies in question, following on from that used by the Japan Foreign Trade Council (JFTC, 2006). 


\section{Brief History of the Sogo Shosha}

Sogo Shosha originated at the time of the opening of Japan to foreign trade in 1868 and were systematically modelled on similar companies overseas such as the British East India Company or Jardine Matheson. These same companies, such as Sumitomo, Mitsui, and Mitsubishi all remain in existence today, although technically speaking they were legally dissolved as a result of their roles during World War II (see Young, 1979; Yoshihara, 1982). For their early history, these groups, then called zaibatsu, not only developed and controlled Japan’s international trade, they also became significant industrial groupings and major financial institutions with both commercial and political reach throughout the Japanese economy. At the time of their break up, Mitsui Bussan was divided into 200 separate companies and Mitsubishi into 139. This break up lasted only as long as the American occupation, however, with the same senior managers allowed to remain in place in the dissected groups quickly moving to rebuild their position from 1952 onwards. However, companies such as Toyota, Sony, Matsushita, and Honda have also developed as export orientated companies in their own right, and, other than in some key areas such as commodity imports, the Shosha have not re-established their monopolistic positions of the pre-war era.

\section{The role and scope of Sogo Shosha roles within Japan}

The share of Japan's international trade accounted for by just the largest 11 Shosha hit a peak of roughly $87 \%$ of all imports and $51 \%$ of all exports in 1990 . By 2002, this figure had fallen sharply, but their share was still significant at $23 \%$ of imports and $12.2 \%$ of exports (UNCTAD, 2005). But it is the more general scope of the Shosha activities that is important in the domestic market and it is this which sets them apart from general trading firms elsewhere. Table 1 summarises the financial results to March 2006 of the leading six Sogo Shosha. It shows clearly just how large these groups are and together they consist of more than 3,600 companies. 
When the results of group companies are amalgamated, total income for each group is extremely large. Toyota, Japan's largest single company, is smaller than each one of the top four Shosha and the combined total income for these six groups is larger than the GDP of Belgium at current exchange rates.

(Table 1 about here)

It is the scope of the activities of each group that makes Shosha so important and so powerful throughout the Japanese economy. After the War, Shosha extended credit to companies through their financial arms, developing links and dependencies that went even further than the groupings already described. Trade related activities were encouraged, and the Shosha have aimed for very high sales volumes over a long term and based their business on stable supply flows. Although such a position of wide-ranging economic support for Japanese firms alone has precluded their transformation into trans-national corporations, it does mean that Shosha are highly influential and have been directly involved, especially through their banking arms, right down to the level of the SME in Japan (Uesugi and Yamashiro, 2005; Kawai, 2003; The Economist, 2006).

Since the early 1990s, however, many of the connections between Japanese companies and single Shosha groups have been broken irrevocably (see The Economist, 2000; Miwa and Ramseyer, 2002; 2005). As a result, Shosha have shifted the focus of their businesses away from purely facilitating international trade and have begun to establish large company group portfolios within domestic Japanese distribution (JFTC, 2000; 2001; Flath, 2002). The acquisition of retail companies and the establishment of their own, new retail chains represents a new direction in Sogo Shosha strategy. With their existing international supply networks, Shosha appear to be placing themselves at the vanguard of consumer goods retailing in Japan with interests in a wide range of product sectors, and primarily in food. 


\section{The business roles of Sogo Shosha: theoretical issues}

Past literature on GTCs, including the Sogo Shosha, has concentrated largely on their role in international trade, particularly in Asia. Historically, however, this role has been one of distribution intermediaries with less involvement in marketing functions:

The trading companies are reputed to have played a vanguard role in the economic revolution of the Far East...They are experienced in extensive global operations and information management; however, in other aspects they must evolve further to become marketing exchange companies. The trading companies concentrated in undifferentiated products..., viewed their operations from a nationalistic base and oriented themselves to suppliers rather than consumers. Many integrated backward into manufacture...Consequently, the organizational resources, information infrastructure, and orientation they evolved were those of a distribution function rather than a marketing function.

(Achrol, 1991, p. 84)

Intermediation also takes the form of consulting, introduction, sourcing, and facilitating that may not involve actual selling of goods in any direct form (Roehl, 1983; Rauch, 1996). As Ellis (2003, pp. 1686-9) notes, both agency theory and transaction cost analysis theory suggest reasons for the modus operandi of trading companies. Agency theory explains the role of ITIs as brokers by providing risk reduction for trading between partners, who tend to be geographically and culturally diverse. GTC also reduce transaction costs that, again, arise as the result of trading over distances and/or through cultural and political barriers. In both cases, however, the competitive advantage of offering such services can be short-lived as both first and third parties may well become capable of dealing directly with each other in the longterm. In addition, such theory overlooks the fact that trading companies are frequently active as market-makers and value creators due to their ability to work in diverse markets. Ellis 
characterises these traders as operating at the boundaries between groups, feeding on the knowledge gap between buyers and sellers, exploiting price differentials, and reducing risk (Ellis, 2003, p. 1691).

Long-term survival and growth for trading firms relies, therefore, on their ability to create new and often diverse opportunities, and to maintain a widely dispersed network of business. This network is likely to be highly dynamic and, as in the case of the Shosha, consists of a huge variety of skills and business fields. Ellis concludes his analysis by relating ITI activities to structural hole theory (Burt, 2000), whereby Shosha are able to fill gaps in a market by aligning complementary resources or information (Ellis, 2003: p. 1692)

For these reasons, it has been suggested that the Soga Shosha would disappear as the Japanese product mix moved to more sophisticated, differentiated goods, because these products would require trade services such as brand-name development and after-sales service that have not been part of their traditional mode of operation (Sakakibara and Serwin, 2000, 48). Nevertheless, for the past two decades, Shosha have worked to broaden their business profile by expanding beyond their role as GTCs or ITIs as described in the literature and into more direct roles within the domestic Japanese market. As a result, much of Achrol’s (1991) summary no longer applies. Today, the management functions provided to domestic businesses by the Shosha mirror the abilities they learned through their traditional role of ITIs.

\section{Japanese distribution changes}

\section{The consolidation of distribution channels}

Japanese distribution has long been characterised by a high degree of fragmentation. According to the most basic figures, while the number of retail and wholesale outlets has fallen by huge numbers over the past two decades, in 2004, there were still 375,378 wholesale outlets and 1,238,296 retail outlets in Japan (METI, 2005). Much of the Japanese academic literature 
continues to emphasise the importance of the wholesale sector in Japan (for example Narui and Flath, 1993; Narui and Torii, 2000; Maruyama, 2000; Maruyama, 2004; Torii and Narui, 2004). This discussion relates to the multilayered nature of the system and takes pains to justify the traditional system, claiming that it is more efficient in the context of the Japanese business culture. Yet the traditional analysis overlooks two points: first these are outlets and not businesses, and second, there is a large and growing concentration of transactions among the very largest outlets (Lohtia and Subramanian, 2000).

As Figure 1 illustrates, the largest outlets, employing more than 20 people, account for only 10 per cent of all outlets, but for more than 66 per cent of total sales. Small wholesale outlets exist to facilitate the bulk breaking from other, larger vendors, but add little additional value to the supply chain. Indeed, it is the reduction in importance of this traditional system that has been a feature of changes in wholesaling in the 1990s.

(Figure 1 about here)

Goldman (1991) concluded that the Japanese distribution system was closely related to Japan's internal political economy rather than to institutional structure, arguing that modernization, while constrained by traditional internal structures, was already taking place, led by more innovative firms outside the traditional structure. More recently, the changes predicted by Goldman have been studied in more depth (see, for example, Maruyama, 2004; MeyerOhle, 2004; Torii and Narui, 2004; Larke and Causton, 2005). The key feature of these changes has been the shift in channel power away from manufacturers and towards retailers.

\section{The entry of Sogo Shosha into domestic distribution channels}

Some recent work discusses the growing influence of retailers within domestic channels, the shortening of wholesale channels, and the direct involvement of Shosha (Torii and Narui, 2004; Larke and Causton, 2005; and Larke, 2005). In a limited number of cases, such as 
Summit, owned by Sumitomo since the 1950s, or Ryoshoku, a subsidiary of Mitsubishi, Shosha have had a long interest in domestic distribution (Azuma and Fernie, 2001). In addition, since the 1980s Shosha have been active as master licensors of overseas luxury brands, but this was once-removed from consumer contact as brands were passed to sub-licensees in the vast majority of cases. Beyond these exceptions, however, Shosha domestic interests were limited and almost entirely wholesale in nature.

In 1994, Daiei began collaborating with Marubeni to supply food from China. This resulted in Marubeni taking a significant shareholding in Maruetsu, a Daiei affiliate, and allowed Marubeni to leverage its food wholesale group. A decade later, when Daiei finally succumbed to bankruptcy administration, Marubeni led the group of companies charged with the chain's rehabilitation and became the controlling owners of Daiei in August 2006.

This was the first of a series of moves towards direct control of retail companies and the consequent expansion of wholesale operations by the five leading Shosha. This change is still not at all well documented and has received little study even in Japanese. The extent of Shoshas' new found interests in domestic food wholesaling can be seen in Table 2 which presents the leading 20 food wholesalers by sales in 2005 (financial year) and the various affiliations to Shosha groups.

(Table 2 about here)

Although the single largest food wholesaler was Kokubu, Mitsubishi, Itochu, and Mitsui all feature prominently within the ranking. Total wholesale food sales for 2005 were $¥ 43.892$ trillion according to METI statistics. On this basis, Kokubu had a total share of the market of some 3 per cent with Ryoshoku, Mitsubishi’s primary food wholesaling subsidiary, just a little behind. However, if the shares of all the companies in which Mitsubishi is the leading or sole shareholder are totalled, the group has a market share of 5.05 per cent, and this is for companies that rank within the top 20 firms alone. For all the leading Shosha, ties with food 
wholesale companies extend well beyond the leading 20 firms, leading to an unprecedented level of concentration into the hands of this small number of groups.

Further, Shosha interests in retailing is less pronounced but growing. The acquisition of Familymart, the third largest convenience store chain, by Itochu in 1999 was followed by Mitsubishi acquiring a controlling stake Lawson, the number two chain, and by the acquisition of stakes in several supermarket companies. Marubeni now controls Daiei and Maruetsu and, more recently, Tobu Stores. Table 3 summarises the retail interests of the Shosha. It includes 11 of the leading 25 retailers in Japan by sales for 2005, but it should be pointed out that it is by no means complete, with major brand interests omitted.

(Table 3 about here)

The domestic distribution interests of the Shosha have grown within the past decade and are likely to continue to expand. In addition, the scope of their domestic business, now covering all stages of the channel, has taken the Shosha beyond the models described in the literature on GTC and ITIs. In that literature, the underlying assumption is that an ITI acts as an intermediary, as with Achrol's definition (1991), but the Shosha are now indeed marketing companies that have extended their interests and activities down to the level of the consumer.

Shosha are no longer just intermediary facilitators, and now aim to exploit their own international supply chains in addition to providing intermediary logistics services to other retail companies. So why have the Shosha acted now, and what are the long-term implications for both themselves and for distribution in Japan as a whole? 


\section{Why Sogo Shosha have taken on domestic distribution roles}

\section{The concept of embeddedness and Sogo Shosha suitability}

In order to understand the reasons behind this recent shift towards greater consumer orientation by the Sogo Shosha, it is useful to return to Goldman's (1991) assertion that Japan’s distribution system is a product of its internal political economy. On this basis, change is more likely to come from within and fit with the expectations and traditions associated with the business culture even when the result is major upheaval and change. Historically, the Shosha are an integral part of the internal political economy with an established interest at the upstream end of distribution channels. They are perfectly placed, therefore, to instigate and influence changes throughout the system, a position that is further strengthened by their sheer size.

In other words, Sogo Shosha are embedded within the political economy (Brahm, 1993).

Embeddedness has three dimensions as defined by Hess (2004):

1. Societal embeddedness. Network actors, be they individuals or collectives, have a history that shapes their perception, strategies and actions, which therefore are path-dependent. This represents their local/ regional/ national 'culture' and is taken with them if they operate abroad, even as they are exposed to different foreign cultures.

2. Network embeddedness. This is about the connections between actors, regardless of their locations. It is also about the notion of embedding and disembedding as dynamic relations within networks.

3. Territorial embeddedness. This relates to the degree to which foreign actors build considerable links to the actors present within foreign host localities. 
Through their history, the Sogo Shosha are embedded in the societal networks or internal political economy of their home economy, have a proven record of political support, and numerous business allegiances. This societal embeddedness has been transplanted overseas in that, first, they have approached societal relationships in other countries in similar ways to those they are familiar with in Japan, and second, they remain committed to Japan in their dealings overseas, rather than becoming trans-national corporations that are disembedded from their societal networks.

In terms of network embeddedness the Shosha are built around networks of actors both in terms of their own huge groups of companies, but equally from their networks of customers and clients (Dicken and Miyamachi, 1998). Leveraging this network is a key competitive advantage for Shosha (Ellis, 2001, 2003), but so is their access to the domestic market where they are able to co-ordinate supply throughout distribution channels, both through members of their own networks and equally between their own companies and third-parties. Furthermore, while there are many internationally active companies in Japan, the majority are export orientated with few working in both import and export simultaneously. This has allowed Shosha to establish themselves as primary suppliers for a large range of products and services that require overseas procurement. A key example is represented by the many luxury brands for which the Shosha act as exclusive master licensors, but almost always sublicensing to intermediary domestic companies and almost never becoming directly involved in the retail supply of these brands.

Such network embeddedness presents Sogo Shosha as the almost ideal intermediaries suited to manage and rebuild parts of the distribution system. They are societally embedded and therefore an acceptable link to traditional business culture, but have the ability to leverage networks that extend far beyond the domestic market and to work within the global economy. Internationally orientated retail companies such as Fast Retailing, Ryohin Keikaku and Five 
Foxes all make considerable use of Shoshas’ OEM production planning and management, consulting and logistical expertise. Through their global networks and by working with other Japanese firms as they move overseas, Shosha are replicating these functions in foreign markets, establishing, therefore, a territorial embeddedness too.

In summary, Shosha find themselves in the unique position of not only extending Japanese distribution channels both into and out of the domestic market, their societal embeddedness allows them to offer an acceptable alternative whereas some similar actors, notably overseas retailers moving into Japan, may not.

\section{International supply chain and economies of scale}

Sogo Shosha are positioned well to influence the development of large global retailers. Japan has long been seen as a problematic market for foreign retailers to enter and its history is littered with cases of failure. One of the overriding factors in the success of the world's largest retailers, however, is their access to global supply networks. Global retailers have largely been responsible for developing such supply networks as a consequence of their own internationalisation. As companies operate in more and more countries, they require access to a larger volume of product and also have access to markets that will sell that volume of product (Coe and Hess, 2005).

To date, Japanese retail companies have followed this model. Although all of Japan's largest retailers organise some imports themselves, it has been the Sogo Shosha that have been mostly responsible for supplying retailers with imported product. Their traditional, specialist import functionality allows for lower costs and fewer bureaucratic problems, presenting an attractive alternative to direct importing by retailers themselves. Consequently, the supply chains organized by the Shosha are the nearest equivalent that Japan has to the global product supply models operated by the retailers such as Wal-Mart, Carrefour and Tesco. 
In this respect, as domestically focused retail companies reach their maximum ability to grow, along with various external pressures from the slowing economy and greater market competition, it was an obvious strategic move for the Shosha to step in and take retail management into their own hands. Furthermore, while the apparel sector has evolved only recently into one that is almost entirely import driven, food has long been a largely imported commodity and food supply has, again, been the province of the Shosha - often on an exclusive basis. With their existing food wholesale businesses in place, it was logical for them to begin expanding the volume capacity of these businesses and, in order to complete their networks within Japan, take every opportunity to expand into retailing too.

\section{Transaction costs and information needs}

Following on from the previous points, it is possible to re-apply the transaction cost analysis of Roehl (1983) and Sakakibara and Serwin (2000). Network embeddedness and international supply chains help to show how Shosha are able to step into the wholesaling role within Japan but not necessarily why they would want to do so. Considering their activities at that time, Roehl argued that Shosha could overcome some of their information disadvantages with other firms by concentrating on repetitive transactions and thus being able to use the information gathered from successive transactions to reduce their costs (p. 125).

As noted above, heavy investment in IT-related data gathering at the retail end of the consumer supply chain has changed the role of the intermediaries in the channel significantly. Consequently, on the one hand, Shosha have found that the owners of many foreign brands have chosen to take back control of their brands in Japan - and have then used their deeper understanding of the brand and their target customers to improve their sales (see Larke and Causton, 2005, pp. 53-64). This reinforces the comments by Sakakibara and Serwin (2000) 
that Sogo Shosha do not have the skills for brand-name development, although there are significant exceptional cases for a small number of brands.

On the other hand, 'opportunistic' moves by Shosha into the convenience store and supermarket sectors have provided them with access to new retail skills and to new types and greater volume of information. They are in a position to better understand the changes that they face and to see how they can try to control the development of the systems that support Shoshas' group operations.

The expansion of domestic wholesale activities, therefore, indicates recognition that the traditional role of wholesaling is set to change radically, if not disappear altogether as concentration in the retail sector allows retailers to exercise greater channel power. Yet, if a retail chain is only as good as its supply chain, then controlling that chain or bringing it in-house would be beneficial under some circumstances. Particularly for those Shosha with substantial retail interests, complete control of supply chains makes the best use of the available information, reduces many of the other costs associated with transactions, and enables the purchasing and supply elements of a Shosha group to improve their bargaining positions. As non-Shosha firms improve their own information systems, supply chain integration also prevents the Shosha from being placed in less powerful asymmetric relationships with retailers, including those entering Japan from overseas.

Therefore, to say that the Shosha are expanding their share of the wholesale sector is perhaps to overlook the fact that their involvement may also change the sector in fairly radical and permanent ways. Smaller, specialist wholesalers will remain as providers of information about specialist products and as suppliers in locations where larger wholesalers cannot operate economically. Large wholesalers will become more strongly aligned with the expressed needs of the retail groups - whether they are part of a particular Shosha group or not. 
It needs to be recognized, however, that there are dangers here for both Shosha and the wider Japanese economy. For the foreseeable future the wholesale supply chains set up by the Shosha (along with their production and retail interests) are likely to remain as groups of connected and/or inter-related firms that deal with one another on some form of favoured, although possibly not exclusive, basis. As the Shoshas' experience increases, so these links are likely to deepen and the level of co-ordination will increase. But they will be neither a single exclusive supply chain nor a real market. By internalising the information and binding the wholesalers more closely to the retailers there is a danger that Shoshas begin to focus on what they can provide to the retailer or consumer, rather than using their consumer data to drive the product supply alone. An overly controlled chain therefore might drive out innovation and over time become less inefficient, threatening both the Shosha controlled wholesalers and any retailers with whom they have strong ties.

\section{Conclusions and Further research}

It is clear that Sogo Shosha are increasing their involvement in the domestic Japanese distribution sector through their investment in both retailers and wholesaling firms. Through their sheer size they are able to influence significantly the behaviour of other players in these sectors and through their wide links and experience they are also facilitating both the import of goods into Japan and the internationalisation of Japanese retailers. In many ways, they are imposing practices and disciplines on the Japanese wholesaling sector that mirror those of large retailers in other countries. By binding together a wide range of channel players with flows of information and expertise, as well as flows of product, Shosha will continue to have a major influence on the changes taking place in the distribution channel in the years to come.

Whilst there have been some efforts to document and map these recent changes in the Japanese wholesale sector (e.g. Meyer-Ohle, 2004; Larke and Causton, 2005), there is a pressing 
need for more work to be done in this area. In tune with Ellis’s (2003) comments, analysis of both the Sogo Shosha and the Japanese distribution sector has waned in recent years because of a widespread belief that they are moribund. Yet, it is clear that major changes have been taking place beneath the surface that are beginning to affect the sector as a whole and these changes are likely to be important for both Japanese retailers and foreign retailers and brands wanting to trade in Japan in the future.

There is a wide range of future research in this area that could prove to be of benefit. In addition to mapping the changes to the sector, these might include a reworking of the efforts to use transaction cost analysis to establish the basis of the competitive advantage of the Sogo Shosha. Their move into the domestic wholesale and retail sectors is not covered by the work of those such as Roehl (1983) that focused on large lots and recurrent contracts in commodity trading. Equally, Sogo Shosha would seem to be clear candidates for analysis as learning organisations, looking at how the parent companies can instil a sense of organizational purpose into the wholesale groups that they now control and how information and experiences can be shared between wholesalers, retailers and suppliers in ways other than just through contractual relationships.

Whether or not Japanese wholesalers continue to hold a separate and distinctive place in the distribution sector or are absorbed into Sogo Shosha-controlled supply chains, the sector is likely to undergo significant change in the years to come and will provide many opportunities for further research in a number of areas.

\section{ACKNOWLEDGEMENTS}

Keri Davies would like to acknowledge the financial assistance from the Japan Foundation Endowment Committee which funded the travel involved in the preparation of this paper. 


\section{REFERENCES}

Achrol, R.S. (1991) 'Evolution of the marketing organization: new forms for turbulent environments,' Journal of Marketing, 55(4), 77-93.

Azuma, N. and Fernie, J. (2001) 'Retail marketing strategies and logistical operations at a Japanese grocery supermarket chain - case study of Summit Inc', International Journal of Retail and Distribution Management, 29(6), 282-297.

Brahm, R., 1993, 'Globalization and Strategy Content Research: Critical Reflections and New Directions', 3-21 in: Shrivastava, P, Huff, A. and Dutton, J. (eds), Advances in Strategic Management, London : JAI Press.

Burt, R. S. (1992). Structural Holes: The Social Structure of Competition. (Cambridge, MA: Harvard University Press).

Coe, N.M. and Hess, M. (2005) 'The internationalization of retailing: implications for supply network restructuring in East Asia and Eastern Europe', Journal of Economic Geography, 5(4), 449-473.

Dicken, P. and Miyamachi, Y. (1998) 'From noodles to satellites': the changing geography of the Japanese sogo shosha, Transactions of the Institute of British Geographers, 23(1), 55-78.

Economist, The (2000) Japan's Keiretsu: Regrouping, 23 November.

Economist, The (2006) Back in Business: Japan’s banks have structured and consolidated, 18 May.

Eli, M. (1990) Japan Inc. Global strategies of Japanese trading corporations. (London: McGraw Hill).

Ellis, P. (2001) 'Adaptive strategies of trading companies, International Business Review, 10, 235-259.

Ellis, P. (2003) 'Social structure and Intermediation: Market-making Strategies in International Exchange,’ Journal of Management Studies, 40(7), November, 1683-1703.

Flath, D. (2002) Distribution Keiretsu, FDI and Import Penetration in Japan, University of Columbia Working Paper 1999, May.

Goldman, A. (1991) 'Japan’s Distribution System: Institutional Structure, Internal Political Economy, and Modernization,’ Journal of Retailing, 67(2), Summer, 154-183.

Hess, M. (2004) 'Spatial' relationships? Towards a reconceptualization of embeddedness,' Progress in Human Geography, 28(2), 165-186.

JFTC (Japan Foreign Trade Council) (2000) The 21st Century as an Age of Advancement with the rest of Asia. New Roles for Japanese Trading Firms. (Tokyo: JFTC).

JFTC (Japan Foreign Trade Council) (2001) Transformation of the 'Sogo-Shosha' in the IT Age. Strategies for the successful eMarketplace. (Tokyo: JFTC).

JFTC (Japan Foreign Trade Council) (2006) http://www.jftc.or.jp, 30 July.

Kawai, M. (2003) Japan's Banking System: From the Bubble and Crisis to Reconstruction, PRO Discussion Paper Series, No. 03A-28, Ministry of Finance. 
Kensy, R. (2001) Keiretsu economy - new economy? Japan's multinational enterprises from a postmodern perspective. (Basingstoke: Palgrave).

Kojima, K. and T. Ozawa (1984) Japan's General Trading Companies: Merchants of Economic Development, (Paris, OECD)

Larke, R. (2005) 'Restructuring the Japanese distribution industry: a shift in power relationships within the supply chain', Conference paper presented at the Third Asian Distribution Conference, March 2005.

Larke, R. and Causton, M. (2005) Japan - A Modern Retail Superpower. (Basingstoke: Palgrave Macmillan).

Lohtia, R. and Subramaniam, R. (2000) Structural transformation of the Japanese retail distribution system, Journal of Business and Industrial Marketing, 15(5), 323-339.

Maruyama, M. (2000) 'Japanese Wholesale Distribution: Its Features and Future,' 19-32 in: Czinkota, M.R. and Kotabe, M. (eds) Japanese Distribution Strategy. (London: Business Press).

Maruyama, M. (2004) 'Japanese Distribution Channels,' The Japanese Economy, 32(3), Fall, 27-48.

METI (Ministry of Economy, Trade and Industry) (2005) Advanced Report of Census of Commerce 2004 (Heisei 16 Nen Shogyou Toshi Chosa Sokuho), 31 May, (Tokyo: METI).

Meyer-Ohle, H. (2004) 'Walking with dinosaurs: general trading companies in the reorganization of Japanese consumer goods distribution,' International Journal of Retail and Distribution Management, Volume 32, No. 1, 45-56.

Miwa, Y. and Ramseyer, J.M. (2002) 'The Fable of the Keiretsu', Journal of Economics and Management Strategy, 11(2), Summer: 169-224.

Miwa, Y. and Ramseyer, J.M. (2005) 'Does Relationship Banking Matter? The Myth of the Japanese Main Bank’, Journal of Empirical Legal Studies, 2(2): 261-302.

Narui, T. and Flath, D. (1993) 'The Complexity of Wholesale Distribution Channels in Japan,’ 83-98 in: Czinkota, M.R. and Kotabe, M. (eds) The Japanese Distribution System. Opportunities and Obstacles. Structures and Practices. (Chicago: Probus).

Narui, T. and Torii, A. (2000) 'Long-Term Manufacturer-Distributor Relationships,' 135-53 in: Czinkota, M.R. and Kotabe, M. (eds) Japanese Distribution Strategy, (London: Business Press).

Rauch, J.E. (1996) Trade and Search: Social Capital, Sogo Shosha, and Spillovers, Working Paper 5618, National Bureau of Economic Research, Cambridge, MA.

Roehl, T. (1983) A Transactions Cost Approach to International Trading Structures: The Case of the Japanese General Trading Companies, Hitotsubashi Journal of Economics, 24, 119135.

Sakakibara, M. and Serwin, K. (2000) 'U.S. Distribution Entry Strategy of Japanese Manufacturing Firms: The Role of Keiretsu,' Journal of the Japanese and International Economies, 14, 43-72. 
Torii, A. and Narui, T. (2004) 'On the Length of Wholesale Marketing Channels in Japan,' The Japanese Economy, 32(3), Fall, 5-26.

Uesugi, I. and Yamashiro, G.M. (2005) ‘Trading Company Finance in Japan’, International Journal of Business, 11(1), Winter.

UNCTAD (United Nations Conference on Trade and Development) (2005) 'New Role for Japan's Sogo Shosha As They Shift From Manufacturing to Services,' UNCTAD Information Note 2005/002, January 20th.

Van Hoek, R.I. (1999) 'Postponement and the reconfiguration challenge for food supply chains,' Supply Chain Management, 4(1), 18-34.

Yonekawa, S. (1990) General Trading Companies in a Comparative Context, Chapter 2 in: Yonekawa, S (ed) General Trading Companies: A Comparative and Historical Study, (Tokyo: United Nations University Press).

Yoshihara, K. (1982) Sogo Shosha. The Vanguard of the Japanese Economy, (Oxford: Oxford University Press).

Yoshihara, H. (1987) The Business History of the Sogo Shosha in International Perspective, pp. 337-353 in: Yonekawa and Yoshihara (eds) Business History of General Trading Companies. Proceedings of the $13^{\text {th }}$ International Conference on Business History, (Tokyo: University of Tokyo Press).

Yoshino, M.Y. (1976) Japan’s Multinational Enterprises, (Cambridge (Mass.): Harvard University Press).

Yoshino, M.Y. and Lifson, T.B. (1986) The Invisible Link. Japan's Sogo Shosa and the Organization of Trade, (Cambridge (Mass): MIT Press).

Young, A.K. (1979) The Sogo Shosha: Japan's Multinational Trading Companies, (Tokyo: Charles E. Tuttle). 
Table 1: The largest six Sogo Shosha by Group Income, 2006

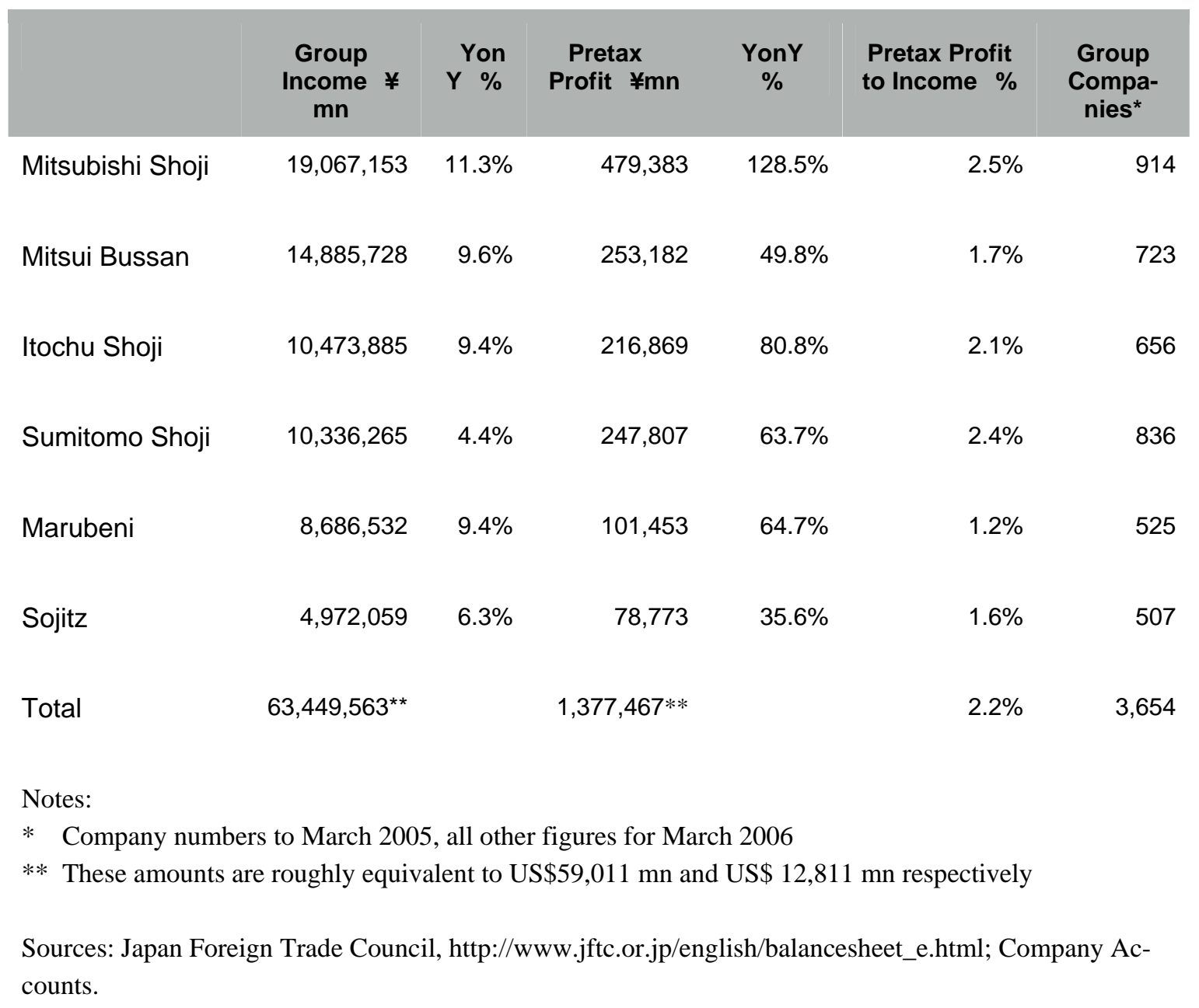


Table 2: Leading food wholesale companies in Japan, 2005

\begin{tabular}{|c|c|c|c|c|c|c|}
\hline & & $\begin{array}{l}\text { Sales } \\
\quad ¥ m n\end{array}$ & $\begin{array}{r}\text { YonY } \\
\%\end{array}$ & $\begin{array}{l}\text { Operat- } \\
\text { ing } \\
\text { Profit } \\
\quad ¥ m n\end{array}$ & $\begin{array}{c}\text { YonY } \\
\%\end{array}$ & $\begin{array}{c}\text { Op PI } \\
\text { Sales } \\
\quad \%\end{array}$ \\
\hline 1 & Kokubu & $1,322,160$ & 6.6 & 6,244 & 25.4 & 0.47 Business tie-up with Mitsui Shokuhin \\
\hline 2 & Ryoshoku & $1,267,412$ & 19.4 & 11,799 & 30.3 & 0.93 Mitsubishi Group \\
\hline 3 & Nihon Access & 817,192 & 5.8 & 2,860 & 57.9 & 0.35 Itochu Group \\
\hline 4 & Itochu Shokuhin & 536,172 & 6.0 & 5,441 & 3.7 & 1.01 Itochu Group \\
\hline 5 & Mitsui Shokuhin & 506,434 & 2.5 & 1,786 & 17.7 & 0.35 Mitsui Group \\
\hline 6 & Kato Sangyo & 500,265 & 3.5 & 6,404 & 6.4 & $\begin{array}{l}\text { 1.28 Sumitomo leading shareholder, also shares by } \\
\text { Mitsubishi, Mitsui }\end{array}$ \\
\hline 7 & Nihon Shurui Hanbai & 430,549 & 6.0 & 1,252 & 245.6 & 0.29 \\
\hline 8 & Meijiya & 424,371 & $(6.5)$ & - & - & - Mitsubishi Group \\
\hline 9 & Asahi Shokuhin & 344,542 & - & - & - & - Mitsubishi leading shareholder \\
\hline 10 & Nishino Shoji & 314,434 & 2.7 & 1,069 & $(43.2)$ & 0.34 Itochu Group \\
\hline 11 & Food Service Network & 281,767 & & 287 & & 0.10 Mitsubishi Group (100\%) \\
\hline 12 & Yamae Hisano & 250,136 & 1.2 & 3,644 & 7.3 & 1.46 \\
\hline 13 & Starzen & 233,103 & 12.6 & 3,297 & 53.0 & $\begin{array}{l}\text { 1.41 Shares held by Mitsui Bussan \& Mitsui group } \\
\text { members }\end{array}$ \\
\hline 14 & Sanseiya & 202,239 & 2.8 & 2,037 & $(0.5)$ & 1.01 \\
\hline 15 & San-esu & 192,598 & 2.2 & 1,705 & $(18.1)$ & 0.89 Mitsubishi Group (89.6\%) \\
\hline 16 & Izumikku & 188,500 & & & & \\
\hline 17 & Maruichi Sansho & 178,354 & $(2.9)$ & 1,931 & 207.0 & 1.08 Mitsubishi leading shareholder \\
\hline 18 & Toho & 164,529 & 4.2 & 2,463 & $(16.8)$ & 1.50 \\
\hline 19 & Takayama & 161,492 & 0.4 & 1,354 & $(43.1)$ & 0.84 \\
\hline 20 & Daido Drinks & 153,585 & 6.7 & 6,762 & 28.2 & 4.40 \\
\hline
\end{tabular}

Sources: Company Reports; Nikkei Company Profiles. 
Table 3: List of main retail interests for leading Sogo Shosha

\begin{tabular}{|c|c|c|c|}
\hline Sogo Shosha & Retail chain & Sector & Relationship \\
\hline \multirow[t]{9}{*}{ Mitsubishi } & Lawson & CVS & Leading shareholder \\
\hline & Life Corporation & SM & Leading shareholder \\
\hline & $\mathrm{am} / \mathrm{pm}$ & CVS & Shareholder \\
\hline & Seicomart & CVS & Shareholder \\
\hline & Diamond City & SC & Joint shareholder \\
\hline & Aeon & GMS & Business relationships \\
\hline & Ministop & CVS & IT development \\
\hline & Ryohin Keikaku & SpS & Shareholder \\
\hline & Sanyo Shokai & SpS & Shareholder \\
\hline \multirow[t]{5}{*}{ Mitsui Bussan } & Hanae Mori & SpS & Leading shareholder \\
\hline & Posful & GMS & Shareholder \\
\hline & Seven \& I Holdings & Mixed & Shareholder and business tie-up \\
\hline & Burberry Group & SpS & Shareholder \\
\hline & Duskin & SpS & Shareholder \\
\hline \multirow[t]{7}{*}{ Itochu } & Familymart & CVS & Leading shareholder \\
\hline & Loft & SpS & Shareholder \\
\hline & Millennium Retailing & DpS & Shareholder $†$ \\
\hline & Seven-Eleven & CVS & Shareholder \\
\hline & Uny & GMS & Business tie-up \\
\hline & Tower Records & SpS & Shareholder \\
\hline & San Mark & SpS & Shareholder \\
\hline \multirow[t]{4}{*}{ Marubeni } & Daiei & GMS & Leading shareholder \\
\hline & Maruetsu & SM & Leading shareholder \\
\hline & Tobu Stores & SM & Shareholder and business tie-up \\
\hline & Metro Japan & $\mathrm{C} \& \mathrm{C}$ & Shareholder (JV) \\
\hline \multirow[t]{4}{*}{ Sumitomo } & Summit & SM & Wholly owned subsidiary \\
\hline & Tomads & Drg & Wholly owned subsidiary \\
\hline & Mammymart & SM & Shareholder \\
\hline & Seiyu & GMS & Shareholder \\
\hline
\end{tabular}

Notes: CVS: convenience stores; GMS: general merchandise stores; SM: supermarkets; SpS: specialty stores; Drg: drugstores; C\&C: cash and carry; DpS: department stores; † Itochu is due to sell its stake in Millennium Retailing in 2006 to Seven \& I Holdings.

Source: Nikkei Company Profiles; Company reports. 
Figure 1: Proportion of Outlets and Sales for Wholesale Outlets by Number of Employees, 2004

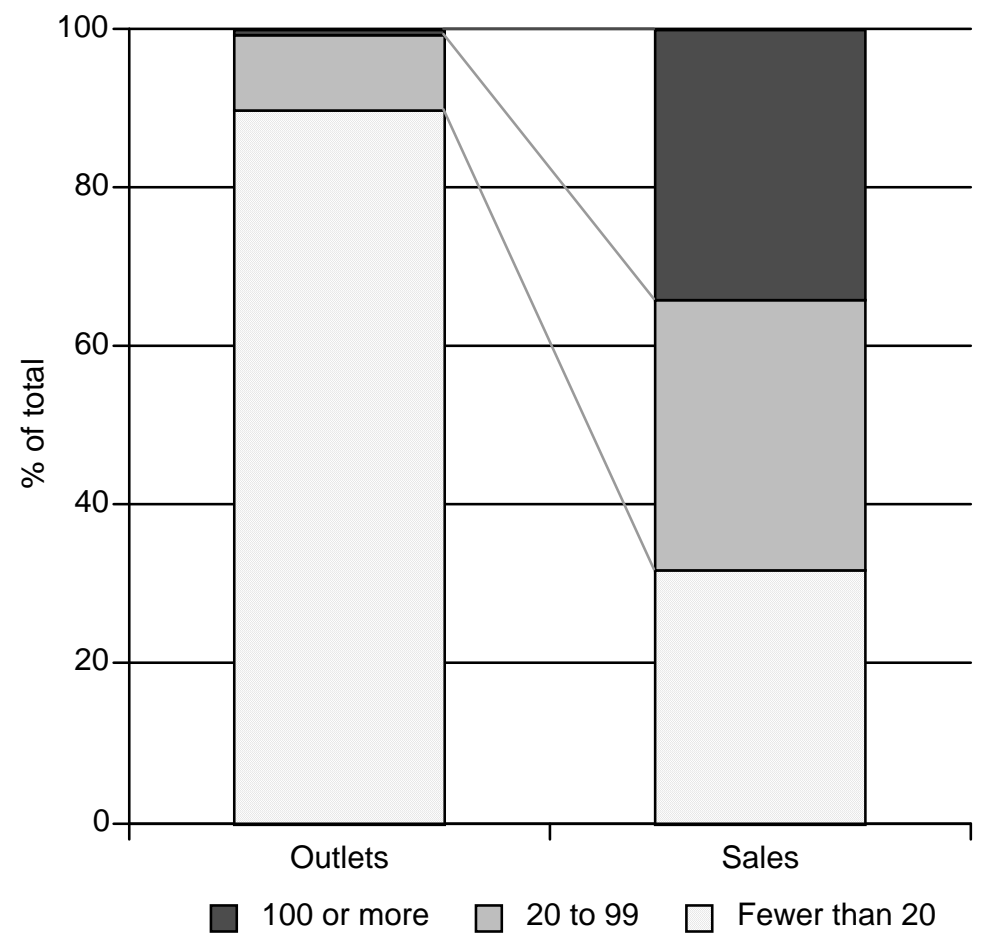

Source: METI (2005) 